\title{
The Extent of School Managers' Practicing of Leadership Styles according to the Managerial Grid Model in Al-Batinah North Governorate, Sultanate of Oman, and its relation to Job Satisfaction of Senior Teachers
}

\author{
Dr. Muhammed Suleiman Al-Jaraida \\ Nizwa University \\ Yousef Obeid Hassan Al-Kayoumi \\ Nizwa University
}

\begin{abstract}
The study aims at identifying the extent of school managers' practicing of leadership styles according to the Managerial Grid Model in Al-Batinah North Governorate, Sultanate of Oman, and its relation to job satisfaction of senior teachers. .To achieve the study objective, a questionnaire consisting of (54) items distributed to (5) key areas, was administrated to (400) senior teachers after verifying its validity and reliability. The study reached a number of findings: the extent of school managers' practicing of leadership styles according to the Managerial Grid Model in Al-Batinah North Governorate, Sultanate of Oman is high and there were no statistically significant differences at the level of $(\alpha \leq 0.05)$ in the extent of school managers' practicing of leadership styles according to the Managerial Grid Model in Al-Batinah North Governorate, Sultanate of Oman due to the gender variable. The results also indicate that there is a direct relation between the type of leadership style adopted by the school managers and the level of satisfaction among teachers. The study introduces some recommendations: school managers should avoid raising differences among teachers while dealing with them as well as teachers should not be hesitated when taking administrative decisions, and should be involved in making these decisions.
\end{abstract}

Key words: the Managerial Grid Model, Job Satisfaction

\section{INTRODUCTION}

The school manager is an educational leader responsible for handling the administrative processes in the school, supervising and motivating teachers, and for the educational program as a whole. School manager is also responsible for coordination and integration among the inputs of the educational learning process, whether human or financial, to achieve the desired educational goals. This requires adopting leadership style affecting teachers' behaviors in order to achieve these goals. Therefore, leadership has received considerable attention from many scientists, so that it has become an important subject for its relation to the human element, which is one of the most important inputs of the educational learning process. The school manager's success as an educational leader depends on harmony between the requirements of the leadership approach necessary for the situation. Hence, this clearly indicates the importance of practicing leadership styles by school managers, so that the goals of the school will come true because of their effects on some organizational variables, such as job satisfaction of teachers.

The subject of leadership styles has gained wide attention since educational and psychological research has demonstrated the role of leadership styles in improving the practical aspects 
within school environment. The manager's behavior affects the employees within the educational institution since if the manager shows good behavior, guidance and counseling, employees will obey him/her willingly. The Managerial Grid Model is developed by Blake and Mouton and examines the leadership styles. It identifies two behaviors for the managerial leader, (a) the concern for people, and (b) the concern for production. Through this Model, five leadership styles are identified, namely: Team Management, Country Club Management, Task Management, Middle of the Road Management, and Impoverished Management. The practice of these leadership styles will differ from one manager to another, so these styles will be the focus of analysis in this study (Rawashdeh, 2009).

Scientists have paid great attention to analyzing the school manager's behavior as an educational leader by adopting two dimensions: school manager's interest in achieving the goals of the school, and his/her interest in teachers' goals and feelings. Based on these two dimensions, the school manager's leadership style is determined (Al Ash, 2010,18). These two dimensions are not separate but interact together during the work of the leader with others. This type of interaction has a significant impact on school manager's thought and behavior, which may in some cases be the path of the leader unconsciously. This means that this Model evaluates the effectiveness of a person's leadership by his/her interest in two dimensions, i.e. concern for teachers and concern for job duties completion (Al- Enezi, 2014,15).

Paying attention to work and teachers appears in many activities or actions exercised by the leader. A leader will pay attention to work by identifying the work activities and proposed plans for accomplishing the work tasks, organizing and coordinating various areas of work, evaluating the work paths in terms of the previous performance standards, and developing the existing areas of work reaching the best results. (Obaidat, 2003; Al-Enzi, 2014). On the other hand, the leader will pay attention to teachers by encouraging workers, respecting their tendencies and responding to their attitudes; providing teachers with the opportunity to engage in decision-making and setting goals; dividing work; defining teachers' standards and allowing teachers to express their opinions and feelings. Moreover, creating harmony, encouraging public expenditure, unifying teachers' opinions, providing advice and counseling for teachers and their career development, reducing their anxiety and maintaining their job stability (Al-Enezi, 2014).

Researchers have widely studied leadership styles for its importance in the success and development of the educational learning process. The school manager's behavior affects the teachers inside the school since if the manager shows good behavior, guidance and counseling, teachers will obey him/her willingly. The Managerial Grid Model is one of the theories developed by Blake and Mouton and examines the leadership styles. It identifies two behaviors for the managerial leader, (a) the concern for people, and (b) the concern for production (Rawashdeh, 2009). In the Managerial Grid Model, Blake and Mouton identify five leadership styles. First, Impoverished Management where the manager is very passive towards teachers and work and show minimum interest. Second, Scientific Management where manager focuses on accomplishing work tasks and production regardless of human relationships or teacher's satisfaction in the school and believes in the necessity to use authority with teachers and impose supervision to accomplish work. Third, Social Club Management where school manager aim at achieving popularity by maintaining the satisfaction of teachers and their love for him/her since the school manager cares about human relations more than work aspects. Fourth, Pendulum Management where school manager is hesitant between caring about teachers and their desires and accomplishment of work tasks and production so that one interest will not overwhelm the other; this is called Middle of the Road Management. Fifth, Team Management where school manager shows great interest in teachers and is careful to 
meet with teachers who can provide the appropriate facts for planning. The leader organizes according to the overall distribution framework of powers and responsibilities. Teachers are kept up-to-date with happening matters by identifying problems, and reconsidering general goals and engaging teachers therein. The manager monitors work continuously to ensure that the plans are running according to their schedules and programs (Obaidat, 2003; Al-Enzi, 2014; Sweet, Bruce, 2016).

The concept of job satisfaction is the most complex concept in Organizational Psychology due to its relation to an emotional status of the individual that is difficult to be measured or studied objectively. Many various definitions indicate the variables related to job satisfaction. Job satisfaction refers to a set of positive or negative feelings inside individuals towards their work/job that reflect the extent of saturation that one perceives to achieve from work (Hammadi, 2016).

Studies that have examined organizational behavior have shown that there is a correlation between the leadership style of the school manager and teachers' job satisfaction, especially when they practice a democratic consultative leadership style. Therefore, they spend the longest period of their day in working at their jobs offices. This is a clear evidence of their satisfaction with their job, increasing the productivity of the school where they work (Dahlan, 2013).

Trough theoretical literature review related to the subject matter of the study, it has been noted that studies were few, especially Arabic and Omani studies in particular. There was no study conducted on educational leadership styles according to the Managerial Grid Model of Blake and Mouton, and its relation to teachers' job satisfaction in Omani schools. This study aims to highlight and identify the styles of leadership behavior prevailing in public schools in the Sultanate of Oman according to this theory and its relation to job satisfaction of teachers from their point of view.

\section{Study Problem \& Questions:}

The success of the educational learning process in achieving its goals greatly depends on the effectiveness of school management and this effectiveness lies in improving this process and achieving its goals. Despite the development of leadership theories and although the Ministry of Education in the Sultanate of Oman has paid great attention to school manager as an educational leader, the results of many Omani studies in the educational field confirm there is a defect in the work of school managers. Some of them are still practicing traditional leadership styles such as the autocratic style. This reduces the teachers' relation to their job and this may be caused by the school manager's leadership style (Al- Jsasi, 2015). Due to the importance of the leadership styles and their impact on teachers' job satisfaction, it is necessary to conduct such study to investigate leadership styles needed by school managers and their relation to teachers' job satisfaction in the Governorate. In general, the study specifically tried to answer the following questions:

1. To what extent do school managers practice leadership styles according to the Managerial Grid Model in Al-Batinah North Governorate, Sultanate of Oman?

2. Are there statistically significant differences at the level of $(\alpha \leq 0.05)$ in the extent of school managers' practicing of leadership styles according to the Managerial Grid Model in Al-Batinah North Governorate, Sultanate of Oman due to the gender, academic qualification and experience years?

3. What is the level of job satisfaction among senior teachers in schools of in Al-Batinah North Governorate, Sultanate of Oman? 
4. What is the relation between the extent of school managers' practicing of leadership styles according to the Managerial Grid Model in Al-Batinah North Governorate, Sultanate of Oman, and job satisfaction of senior teachers?

\section{Study Objectives:}

This aims to achieve the following objectives:

1. Identify the extent of school managers' practicing of leadership styles according to the Managerial Grid Model in Al-Batinah North Governorate, Sultanate of Oman

2. Identify the significance of statistically significant differences at the level of $(\alpha \leq 0.05)$ in the extent of school managers' practicing of leadership styles according to the Managerial Grid Model in Al-Batinah North Governorate, Sultanate of Oman due to the gender, academic qualification and experience years?

3. Identify the level of job satisfaction among senior teachers in schools of in Al-Batinah North Governorate, Sultanate of Oman?

4. Identify the relation between the extent of school managers' practicing of leadership styles according to the Managerial Grid Model in Al-Batinah North Governorate, Sultanate of Oman, and job satisfaction of senior teachers?

\section{Study Importance:}

The importance of this study is as follows:

- By examining leadership styles of school managers, this study is expected to provide feedback to school managers concerning the extent practicing leadership styles according to the Managerial Grid Model. This will contribute to improving weaknesses and promoting strengths and provide decision makers in the Ministry of Education and the General Directorates of Education with information about leadership styles of school managers in the North Al Batinah Governorate, the Sultanate of Oman according to the Managerial Grid Model to design training programs that contribute to raising the managerial efficiency of the school managers.

- The importance of the study depends on the role of school manager in the execution of educational policies through a procedural system of managerial practices to achieve the desired educational goals.

- Educational researchers, who are interested in school management especially the subject of leadership styles of school managers according to the Managerial Grid Model, are expected to benefit from this study.

- The importance of school manager in the success of the educational learning process, achieving its goals and promoting its jobs and duties.

- The great importance of the population upon which the study will be conducted represented in senior teachers as this study combines teachers' leadership styles with job satisfaction.

- Modernity will give this study a greater importance by revealing the extent of school managers' practicing of leadership styles according to the Managerial Grid Model in Al-Batinah North Governorate, and its relation to job satisfaction of senior teachers in the Sultanate of Oman, especially that there are no previous studies addressing this subject in the Sultanate Oman.

Study Limitations: The study includes the following limits:

Objective Limits: The study includes styles of Impoverished Management, Scientific Management, Social Club Management, Pendulum Management, and Team Management.

Spatial Limits: This study has been conducted on schools of Al-Batinah North Governorate, the Sultanate of Oman.

Temporal Limits: This study has been conducted in 2018/2019 academic year.

Human Limits: This study has been conducted on senior teachers in schools of Al-Batinah North Governorate, the Sultanate of Oman. 
Study Terms: the study includes the following terms:

Leadership: means the leader's influence on his/her subordinates to persuade them to make effective efforts in performance of cooperative activity (Al Har, 2017, 22). In this study, the researcher procedurally identifies leadership as the potentials provided by the leader to the team members through which the leader can influence them making them more effective.

Leadership Style: means the leaders' behavior in any situation during achievement of group goal, which shall be exemplified by the subordinates in their behaviors (Hassan, Ajami, 2007, 26). In this study, the researcher procedurally identifies leadership style as a behavior used by the leader as an executive procedure, oral or written, to gain the trust and cooperation of subordinates and to achieve the school goals with ease.

Managerial Grid Model: It is a theory examines managerial leadership and is developed by Blake and Mouton. It identifies two behaviors for the managerial leader as gird of two axis, namely (a) the concern for people, and (b) the concern for production. It includes five leadership styles: Team Management, Country Club Management, Task Management, Middle of the Road Management, and Impoverished Management (Harim, 1997, 275). In this study, the researcher procedurally identifies Managerial Grid Model as a theory including a set of leadership styles which the school manager can use the appropriate one in leading school staff.

Job Satisfaction: means the individual's inner feeling of satisfaction and psychological and emotional compatibility as a result of satisfying his needs and performance of his job duties in addition to the individual's desire in accomplishment and achievement of his future goals and ambitions (Al- Jasasi, 2016, 22). In this study, job satisfaction is measure by the average scores obtained from the questionnaire describing teachers' job satisfaction prepared for this purpose.

Senior Teacher: (Issan \& Al-Shadi, 2018, 270) explained that the Ministry of Education in Oman has identified the senior teacher as the person who represents the fourth level of educational supervision, administratively follows the school manager and is technically associated with the supervisor of the subject or the field. He also is responsible for teaching and helping teachers develop their teaching potentials and for implementing the educational approaches according to the developed methods and techniques. In this study, the researcher procedurally identifies senior teacher as the supervisor responsible for teaching staff having the same specialty of him and has to follow up them technically and administratively with communicating these follow-ups to the school manager and the educational supervisor of the subject.

\section{SECOND: REVIEW OF LITERATURE}

To the limits of the researchers knowledge, they did not find any studies conducted in the Sultanate of Oman directly related to the subject of this study, while some Arab and foreign studies were found under which this study is included. Below are the most relevant studies to this study:

Richard (2005) conducted a study aimed at identifying the dominant leadership style of the school manager who is the most appreciated one by teachers according to years of experience. A questionnaire was administered to 75 teachers of the eighth grade. The study questions were about the behaviors considered as encouraging by teachers. After analyzing the data, the study reached some results that showed the most important behaviors preferred by teachers, namely: respecting teacher, treating him as a specialist teacher, open door policy, manager's presence and listening to the teacher, justice, honesty, supporting and encouragement of teachers, and helping the teacher in the control of students. The results found that there are differences between the teachers' responses attributed to years of experience. The teachers with little experience from one to five years replied that one the most important behaviors they need to be present in their manager is moral support and open door policy. 
The study (Haddad and Mohafazah, 2010) aimed at examining the prevailing leadership styles among primary school managers in Ajloun Governorate and their relation to employees' job satisfaction from the point of view of the employees themselves. The study sample consisted of (27) managers and (400) teachers selected by simple random sampling. The study used two instruments: One for job satisfaction from the point of view of teachers and the second for measuring the prevailing leadership styles of the primary school managers. The study reached the following results: all members of the study sample received a high degree of job satisfaction while there were no statistically significant differences between the effect of the leadership style and the degree of job satisfaction due to the variables of the study.

Al-Rawqi (2011) conducted a study titled "Leadership Styles of School Principals and their Relation to Job Satisfaction among Secondary School Teachers in Makkah" The study aimed to identify the relation between leadership styles of school managers and their relation to job satisfaction among high school teachers in Makkah. A questionnaire was developed as an instrument to collect data about the teacher. The study sample consisted of 500 teachers and teachers selected by stratified random sampling from different disciplines. The results showed that the degree of job satisfaction among secondary school teachers as for their point of view was high and there was a positive direct correlation with moderate degree between job satisfaction and the democratic style.

Taleb (2013) conducted a study aimed at identifying the gender differences in the management styles of schools in Serbia and the best leadership style in schools in Serbia through the twodimensional Managerial Grid Model, which is based on five leadership styles. To achieve the objectives of the study, the researcher adopted the descriptive approach by developing a questionnaire for leadership using the Managerial Grid Model developed by Blake and Mouton, which is based on the binary grid comprising of concern for people and concern for completing task. The sample consisted of 35 school managers in Serbia. One of the most important results of this study are that people should be considered/viewed regardless of gender. The results also showed that the leadership style does not vary between males and females. One of the general results of the study is the lack of a specific technique of leadership to be adopted in schools in Serbia, but leadership style in schools depends on the nature of the situation through which the school principal is going regardless of gender.

The study of Iqbal and Akhtar (2013) aimed to examine the level of job satisfaction among male and female secondary school teachers in the Islamic Republic of Pakistan. They compared them in terms of certain variables: gender, age, years of experience in teaching and school location. The study population consisted of (2129) teachers including all secondary school teachers in Lahore region. They took a sample divided into two parts: (170) male teachers and (152) females teachers, i.e. $22 \%$ of the entire study population. The researchers adopted the descriptive approach in their study by developing the questionnaire. The most important results of the study were that female teachers are more satisfied than male teachers in matters related to the aspects of work and supervision in the job. There are also no statistically significant differences in job satisfaction due to variables of teaching experience, age, and school location.

The study conducted by Cabansag (2013) referred to in Al-Enezi, 2014, aimed at identifying the prevailing leadership styles practiced by managers at the middle management level, such as the deans of colleges and universities in Cagayan, the Philippines, through the twodimensional Managerial Grid Model and the five leadership styles. The descriptive approach was adopted to achieve the study objectives. The most important results of the study are that managers encounter a number of problems that affect their performance. Other important 
results indicate that the leadership style used in the middle management of managers is the Middle of the Road Management style $(5,5)$. This means that the leader pays attention to people and production equally at the same level, indicating that the individual feeling of job satisfaction towards work is moderate.

The study of Agnihotri (2013) adopted the descriptive approach based on data collection by using the questionnaire. Through this instrument, the researcher sought to determine the degree of teachers' job satisfaction in terms of variables of the educational stages (primary and secondary), gender (male \& female), the level of experience and the level of income in India. The study population consisted of 72 schools in the states of Hamirpur and Himachal Pradesh, divided into 46 primary schools and 26 secondary schools. The study sample consisted of 300 teachers (166 males and 134 females). The most prominent results were that job satisfaction was higher for primary school teachers than for the secondary school teachers, and that there were statistically significant differences due to the gender variable in favor of females.

Dahlan (2013) conducted a study to identify the prevailing leadership styles among secondary school managers in Gaza and their relation to teachers' job satisfaction. The researcher adopted the descriptive approach for being appropriate to the subject of the study. The researcher used two questionnaire to achieve the objectives of the study. One questionnaire to measure leadership styles and the second to measure teachers' job satisfaction. The following styles were used: transformational, democratic, chaotic, and autocratic styles. The study revealed that there are no differences between the scores of the study sample in fields of (nature of work, security, belonging to work, salaries and incentives). One of the most prominent recommendations of the study is the necessity to pay attention to teachers' job satisfaction, and improve and raise it achieving a better level of performance and achievement.

Wijdan (2014) conducted a study entitled "The Extent of Public Secondary School Managers' Practicing of Leadership Styles and their Relation to Job Satisfaction of Teachers from their Point of View in Jerash Governorate". This study aimed to identify the extent of public secondary school managers' practicing of leadership styles and their relation to job satisfaction of teachers from their point of view in Jerash Governorate and to explore the sample members' responses according to variables of gender, academic qualification and experience. The study sample consisted of 280 teachers from Jerash Governorate selected by stratified random sampling. To achieve the study objective, two questionnaires were developed and their validity and reliability were verified. The results demonstrated that the level of job satisfaction among secondary school teachers from their point of view in Jerash Governorate was moderate (Arithmetic Mean was 3.52). The results showed that there were no statistically significant differences at the level of $(a \leq 0.05)$ for the level of job satisfaction among teachers according to gender and experience variables. As for the academic qualification variable, there were statistically significant differences in favor of Masters and above in terms of satisfaction with salary, remunerations and work environment.

The study of Al Jasasi (2016) aimed to identify leadership styles of post-primary schools managers in the Sultanate of Oman according to the Path-Goal Theory from the point of view of school managers and their relation to teachers' job satisfaction. The study sample consisted of 526 managers, and senior teachers selected by simple random sampling. The study was conducted using two instruments: One to measure to what extent post-primary schools managers apply leadership styles according to the Path-Goal Theory, while to measure job satisfaction from the point of view of senior teachers. The study reached some results and recommendations, including: procedural research should be applied to schools and 
directorates to focus on leadership styles that contribute to raise job satisfaction and the Ministry should provide more incentive courses for teachers in job satisfaction and reimplementation of the of the Teacher Incentive Program.

The study of Aldoferi (2017) referred to in Youssef (2017) aimed to study the leadership styles of faculty members of the Public Authority for Applied Education and Training in Kuwait and their relation to the culture of achievement. The researcher adopted the descriptive analytical approach. One of the most important results was that there was a high impact on the leadership styles among the faculty members of the Public Authority for Applied Education and Training.

\section{Study Approach:}

\section{METHOD \& PROCEDURE}

The study adopted the descriptive approach appropriate for this type of studies.

\section{Study Population:}

The study population consists of all senior teachers in the schools of Al Batinah North Governorate (655 senior teachers) according to the statistics of the Statistics Department at the Directorate of Education in Al Batinah North Governorate in the academic year of $2017 / 2018$.

Table (1) Distribution of Study Population according to Schools and Gender

\begin{tabular}{c|c|c} 
Study Population & Number of Schools & Gender \\
\hline Males & 65 & 262 \\
\hline Females & 97 & 393 \\
\hline Total & 162 & 655
\end{tabular}

\section{Study Sample:}

Study sample consisted of 400 senior teachers, i.e. $61 \%$ of the study population selected by the simple random sampling as shown below.

Table (2) Distribution of Study Sample according to the Demographic Variables of the Study

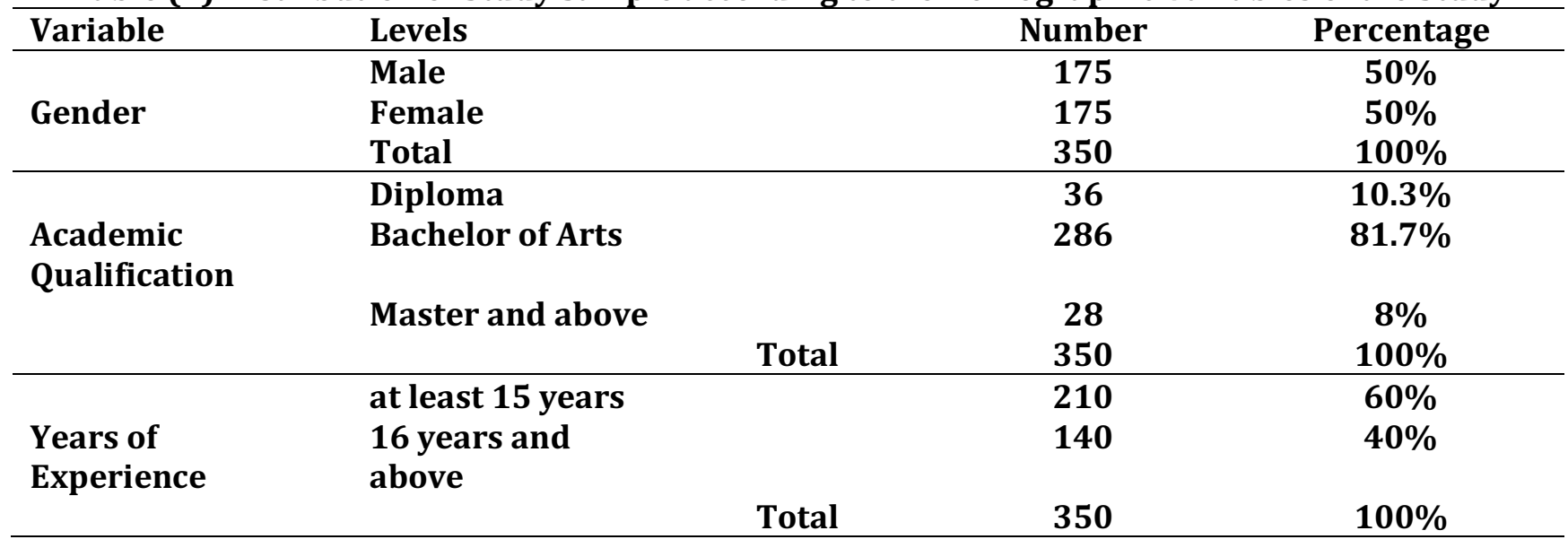

\section{Study Instrument:}

In order to achieve the study objectives, the researchers developed the study instrument after reviewing the theoretical literature and previous studies related to this subject, including the study of Dahlan (2013) and Al-Enzi (2014). The questionnaire consisted of (54) items after arbitration, divided into five main areas and each area includes a number of items. 


\section{Validity of the Study Instrument:}

To verify the validity of the study instrument, the researchers presented the questionnaire to a group of competent arbitrators in Omani universities who have great experience in administrative and educational work in the Ministry of Education and in Omani universities. The number of arbitrators was (12). The arbitrators were asked to express their opinions and observations on the questionnaire items in order to ensure the comprehensiveness of the study instrument in terms of language; items relevance to the areas; deletion, modification or addition of what they deem appropriate. The questionnaire, before submission to the arbitrators, consisted of (60) items distributed to the five areas. Based on the observations of the arbitrators, the final form of the questionnaire became (54) items.

\section{The Reliability of the Study Instrument:}

To verify the reliability of the study instrument, Cronbach's Alpha was used for the areas and the instrument as a whole as shown in Table (3) below.

Table (3) Cronbach Alpha Reliability Coefficients of Styles and the Scale as a whole Scale Styles Items Cronbach's Alpha

\begin{tabular}{lcc} 
First Style: Impoverished Management & 6 & 00.8 \\
Second Style: Scientific Management & 6 & 0.84 \\
Third Style: Social Club Management & 6 & 0.85 \\
Fourth Style: Pendulum Management & 6 & 0.70 \\
Fifth Style: Team Management & 6 & 00.8 \\
\hline Total Score & 30 & 0.85
\end{tabular}

From Table (3), reliability coefficient in each dimension of the instrument is high value of reliability in humanities and an indication of the internal consistency of the dimensions of the instrument. Therefore, all dimensions are considered appropriate for the study purposes.

\section{Study Variables:}

The study includes the following variables:

- Independent Variable: the extent of school managers' practicing of leadership styles according to the Managerial Grid Model in Al-Batinah North Governorate, Sultanate of Oman.

- Intermediate Independent Variables: This study includes three intermediate independent variables:

- Gender: male, female.

- Academic qualification: Diploma, Bachelor of Arts, Master or higher.

- Years of experience: 15 years and less, 16 years and over.

- Dependent Variable: Job satisfaction of senior teachers in the schools of Al Batinah North Governorate, the Sultanate of Oman.

\section{Data Statistical Processing:}

The study used the appropriate statistical, descriptive and analytical processing to reach the results for each of the study questions using the SPSS program as follows:

1. The Alpha Cronbach correlation coefficient was used to confirm the reliability of the study instrument.

2. Arithmetic means and standard deviations were calculated to answer the first and the third questions.

3. T-Test and ANOVA were used to answer the second question.

4. Pearson correlation coefficients were used to answer the fourth question. 


\section{STUDY RESULTS \& DISCUSSION}

First: Results related to the first question, which read:

"To what extent do school managers practice leadership styles according to the

Managerial Grid Model in Al-Batinah North Governorate, Sultanate of Oman?"

To answer this question, the arithmetic means and standard deviations were calculated for scores of the study sample regarding the extent of school managers' practicing of leadership styles according to the Managerial Grid Model in Al-Batinah North Governorate, Sultanate of Oman from the point of view of senior teachers according to Leadership Styles Practicing Scale. To clarify the results of answering this question, the researcher adopted the following arbitration:

Range

Degree of Practice

From 1 to 2.33

low

From 2.34 to 3.67

average

From 3.68 to 5

high

The following Table shows this.

Table (4) the Arithmetic Means and Standard Deviations were calculated for Scores of the Study Sample on the Dimensions of Leadership Styles Practicing Scale in a Descending Order according to the Arithmetic Means

\begin{tabular}{|c|c|c|c|c|c|}
\hline Rank & Number & Styles & $\begin{array}{l}\text { Arithmetic } \\
\text { Mean }\end{array}$ & $\begin{array}{l}\text { Standard } \\
\text { Deviation }\end{array}$ & $\begin{array}{l}\text { Degree of } \\
\text { Practice }\end{array}$ \\
\hline 1 & 5 & Fifth Style: Team Management & 4.29 & 0.72 & high \\
\hline 2 & 3 & $\begin{array}{l}\text { Third Style: Social Club } \\
\text { Management }\end{array}$ & 3.93 & 0.68 & high \\
\hline 3 & 1 & $\begin{array}{l}\text { First Style: Impoverished } \\
\text { Management }\end{array}$ & 2.94 & 0.85 & average \\
\hline 4 & 2 & $\begin{array}{l}\text { Second Style: Scientific } \\
\text { Management }\end{array}$ & 2.39 & 0.58 & average \\
\hline \multirow[t]{2}{*}{5} & 4 & $\begin{array}{l}\text { Fourth Style: Pendulum } \\
\text { Management }\end{array}$ & 2.13 & 0.70 & low \\
\hline & & $\begin{array}{l}\text { Leadership Styles Practicing } \\
\text { Scale in total }\end{array}$ & 3.14 & 0.28 & average \\
\hline
\end{tabular}

Table (4) shows the arithmetic means and standard deviations of the study sample scores in the extent of school managers' practicing of leadership styles according to the Managerial Grid Model in Al-Batinah North Governorate, Sultanate of Oman from the point of view of senior teachers. In the first place came the fifth style "Team Management" with an arithmetic mean of (4.29) and a standard deviation of (0.72). In the second place came the third style (Social Club Management) with an arithmetic mean of (3.93) and a standard deviation of (0.68). In the third place came the first style (Impoverished Management) with an arithmetic mean of (2.94) and a standard deviation of (0.85). In the last place came the fourth style (Pendulum Management) with an arithmetic mean of (2.13) and a standard deviation of (0.70). The general arithmetic mean was (3.14) and the standard deviation was (0.28) indicating that the extent of school managers' practicing of leadership styles according to the Managerial Grid Model in Al-Batinah North Governorate, Sultanate of Oman from the point of view of senior teachers is average. This result may be attributed to leadership skills of school managers as result of their 
experience and knowledge during performing their school duties and tasks. During the official working hours, they face many educational situations in which they must use more than one leadership style during the official working hours so that they can give each situation the appropriate leadership style. This is a result of the great responsibilities assigned to school managers in order to ensure the success of the work in the educational institution, so that their leadership will be more effective and successful. This gives school managers the opportunity to practice leadership styles according to the Managerial Grid Model with varying degrees and according to the situation. This result was consistent with the result of the studies of (Al-Jasasi, 2016; Al Ash, 2010).

\section{First: First Style: Impoverished Management}

Table (5) the Arithmetic Means and Standard Deviations of Items of the First Style (Impoverished Management) in a descending order according to the Arithmetic Means

\begin{tabular}{|c|c|c|c|c|c|}
\hline Rank & Number & Items & $\begin{array}{l}\text { Arithmetic } \\
\text { Mean }\end{array}$ & $\begin{array}{l}\text { Standard } \\
\text { Deviation }\end{array}$ & $\begin{array}{l}\text { Degree of } \\
\text { Practice }\end{array}$ \\
\hline 1 & 6 & Arise disputes among teachers & 3.67 & 1.50 & average \\
\hline 2 & 2 & Hesitate to make any decision & 3.07 & 1.33 & average \\
\hline 3 & 5 & $\begin{array}{l}\text { Satisfied with the teachers' minimum } \\
\text { efficiency }\end{array}$ & 2.91 & 1.29 & average \\
\hline 4 & c & $\begin{array}{l}\text { Give the teacher full freedom to say } \\
\text { whatever he/she wants and whenever } \\
\text { he/she wants }\end{array}$ & 2.69 & 1.31 & average \\
\hline 5 & 3 & $\begin{array}{l}\text { Avoid disputes to keep his/her } \\
\text { position }\end{array}$ & 2.67 & 1.38 & average \\
\hline 6 & 1 & $\begin{array}{l}\text { Slightly interested in teachers and } \\
\text { work alike }\end{array}$ & 2.63 & 1.35 & average \\
\hline & & General Level & 2.94 & 0.85 & average \\
\hline
\end{tabular}

Table (5) shows the general arithmetic means and the general standard deviations of the items of the first style (Impoverished Management) where the general arithmetic means was (2.94) and the general standard deviation was (0.85) with average degree. In the first place came Item (6) "Arise disputes among teachers" with the highest arithmetic mean of (3.67). In the second place came Item (2) "Hesitate to make any decision" with an arithmetic mean of (3.07). In the third place came Item (5) "Satisfied with the teachers' minimum efficiency" with an arithmetic mean of (2.91). In the last place came Item (1) "Slightly interested in teachers and work alike" with an arithmetic mean of (2.63). The general arithmetic mean of this area was (2.94) and the standard deviation was (0.85) indicating that the extent of school managers' practicing of leadership styles according to the Managerial Grid Model in Al-Batinah North Governorate, Sultanate of Oman from the point of view of senior teachers is average according to the Impoverished Management Style. This result may be attributed to the lack of awareness among school managers of the leadership style they exercise, their lack of awareness of the humanitarian aspect of leadership, and their lack of confidence in teachers. This is represented in raising disputes with teachers almost continually because they do not have adequate knowledge of disputes management strategies, their tendency to cliquishness occasionally, hesitation when making decisions, and satisfied with the minimum work of teachers. This result was consistent with the result of the studies of (Al-Jasasi, 2016; Al Ash, 2010). 
Second: Second Style: Scientific Management

Table (6) the Arithmetic Means and Standard Deviations of Items of the Second Style (Scientific Management) in a descending order according to the Arithmetic Means

\begin{tabular}{|c|c|c|c|c|c|}
\hline Rank & Number & Items & $\begin{array}{l}\text { Arithmetic } \\
\text { Mean }\end{array}$ & $\begin{array}{l}\text { Standard } \\
\text { Deviation }\end{array}$ & $\begin{array}{l}\text { Degree of } \\
\text { Practice }\end{array}$ \\
\hline 1 & 12 & $\begin{array}{l}\text { His decisions are final without } \\
\text { discussion }\end{array}$ & 3.23 & 1.34 & average \\
\hline 2 & 11 & Give instructions as orders & 2.89 & 1.30 & average \\
\hline 3 & 9 & Strict in dealing with teachers & 2.54 & 1.10 & average \\
\hline 4 & 10 & $\begin{array}{l}\text { Hold many meetings strict in } \\
\text { dealing with teachers }\end{array}$ & 2.03 & 0.96 & low \\
\hline 5 & 7 & Make decisions alone & 1.89 & 0.92 & low \\
\hline \multirow[t]{2}{*}{6} & 8 & $\begin{array}{l}\text { Care about work more than } \\
\text { anything else }\end{array}$ & 1.78 & 0.83 & low \\
\hline & & General Level & 2.39 & 0.58 & average \\
\hline
\end{tabular}

Table (6) shows the general arithmetic means and the general standard deviation of the items of the second style (Scientific Management) where the general arithmetic means was (2.39) and the general standard deviation was (0.58) with average degree. In the first place came Item (12) "His decisions are final without discussion" with the highest arithmetic mean of (3.23). In the second place came Item (11) "Give instructions as orders" with an arithmetic mean of (2.89). In the third place came Item (9) "Strict in dealing with teachers" with an arithmetic mean of (2.54). In the last place came Item (8) "Care about work more than anything else" with an arithmetic mean of (1.78). The general arithmetic mean of this area was (2.39) and the standard deviation was (0.58) indicating that the extent of school managers' practicing of leadership styles according to the Managerial Grid Model in Al-Batinah North Governorate, Sultanate of Oman from the point of view of senior teachers is average according to the Impoverished Management Style. This result may be due to that school managers have an average focus on school work achievement, and their interests have varied between decision-making for work, directing teachers to achieving pre-planned goals and encouraging them to innovate and adopt the appropriate teaching methods.

\section{Third: Third Style: Social Club Style}

Table (7) the Arithmetic Means and Standard Deviations of Items of the Third Style (Social Club Management) in a descending order according to the Arithmetic Means

\begin{tabular}{|c|c|c|c|c|c|}
\hline Rank & Number & Items & $\begin{array}{c}\text { Arithmetic } \\
\text { Mean }\end{array}$ & $\begin{array}{l}\text { Standard } \\
\text { Deviation }\end{array}$ & $\begin{array}{c}\text { Degree of } \\
\text { Practice }\end{array}$ \\
\hline 1 & 15 & $\begin{array}{l}\text { participate with teachers in their social } \\
\text { events }\end{array}$ & 4.46 & 0.83 & high \\
\hline 2 & 17 & $\begin{array}{l}\text { Manage school based on the principle } \\
\text { of human relations with teachers }\end{array}$ & 4.27 & 0.93 & high \\
\hline 3 & 14 & Support decisions that benefit teachers & 4.02 & 0.97 & high \\
\hline 4 & 18 & $\begin{array}{l}\text { Adopt ideas and opinions of his/her } \\
\text { teachers without imposing his/her } \\
\text { opinion }\end{array}$ & 4.01 & 1.06 & high \\
\hline 5 & 16 & $\begin{array}{l}\text { Careful to avoid cliquishness and } \\
\text { partiality in school }\end{array}$ & 3.88 & 1.19 & high \\
\hline 6 & 13 & $\begin{array}{l}\text { Care about teachers at the expense of } \\
\text { work }\end{array}$ & 2.96 & 1.32 & average \\
\hline & & General Level & 3.93 & 0.68 & high \\
\hline
\end{tabular}


Table (7) shows the general arithmetic means and the general standard deviation of the items of the third style (Social Club Management) where the general arithmetic means was (3.93) and the general standard deviation was (0.68) with high degree. In the first place came Item (15) "participate with teachers in their social events" with the highest arithmetic mean of (4.46). In the second place came Item (17) "Manage school based on the principle of human relations with teachers" with an arithmetic mean of (4.27). In the third place came Item (14) "Support decisions that benefit teachers" with an arithmetic mean of (4.02). In the last place came Item (13) "Care about teachers at the expense of work" with an arithmetic mean of (2.96). The general arithmetic mean of this area was (3.93) and the standard deviation was (0.68) indicating that the extent of school managers' practicing of leadership styles according to the Managerial Grid Model in Al-Batinah North Governorate, Sultanate of Oman from the point of view of senior teachers is high according to the Social Club Management Style. This result may be due to that school managers are more interested to the social relationships and their direct reflections on teachers' job satisfaction. This interest appears through understanding and listening to teachers' opinions continually, taking care of their needs, avoiding what bothers them, avoiding putting them under pressure to work and avoiding being bias while dealing with them. This result is different from the result of the study of (Al - Ash, 2010).

\section{Fourth: Fourth Style: Pendulum Management}

Table (8) the Arithmetic Means and Standard Deviations of Items of the Fourth Style (Pendulum Management) in a descending order according to the Arithmetic Means

\begin{tabular}{|c|c|c|c|c|c|}
\hline Rank & Number & Items & $\begin{array}{l}\text { Arithmetic } \\
\text { Mean }\end{array}$ & $\begin{array}{l}\text { Standard } \\
\text { Deviation }\end{array}$ & $\begin{array}{c}\text { Degree of } \\
\text { Practice }\end{array}$ \\
\hline 1 & 21 & $\begin{array}{l}\text { Attributes the success of the school to } \\
\text { all employees and sometimes to } \\
\text { him/herself }\end{array}$ & 2.36 & 1.13 & average \\
\hline 2 & 20 & $\begin{array}{l}\text { Adopts decisive decisions and } \\
\text { sometimes adopts other ideas and } \\
\text { opinions without imposing his/her } \\
\text { opinion }\end{array}$ & 2.17 & 0.94 & low \\
\hline 3 & 23 & $\begin{array}{l}\text { Deals in a manner not bothering any of } \\
\text { the teachers and sometimes uses } \\
\text { his/her power to control their actions }\end{array}$ & 2.10 & 0.98 & low \\
\hline 4 & 24 & $\begin{array}{l}\text { Consult with all parties in the } \\
\text { educational process in school and } \\
\text { sometimes selects certain parties for } \\
\text { consultation }\end{array}$ & 2.07 & 1.03 & low \\
\hline 5 & 19 & $\begin{array}{l}\text { Manages the school with rough and } \\
\text { smooth and compromises between the } \\
\text { teachers' satisfaction and achieving } \\
\text { productive efficiency }\end{array}$ & 2.05 & 0.94 & low \\
\hline \multirow[t]{2}{*}{6} & 22 & $\begin{array}{l}\text { Takes into account the needs of } \\
\text { teachers in school schedule and } \\
\text { rotation; sometimes distributes roles } \\
\text { according to the interest of work }\end{array}$ & 2.05 & 1.06 & low \\
\hline & & General Level & 2.13 & 0.70 & low \\
\hline
\end{tabular}

Table (8) shows the general arithmetic means and the general standard deviation of the items of the fourth style (Pendulum Management) where the general arithmetic means was (2.13) and the general standard deviation was (0.70) with low degree. In the first place came Item (21) "Attributes the success of the school to all employees and sometimes to him/herself" with the highest arithmetic mean of (2.36). In the second place came Item (20) "Adopts decisive decisions 
and sometimes adopts other ideas and opinions without imposing his/her opinion" with an arithmetic mean of (2.17). In the third place came Item (23) "Deals in a manner not bothering any of the teachers and sometimes uses his/her power to control their actions" with an arithmetic mean of (2.10). In the last place came Item (22) "Takes into account the needs of teachers in school schedule and rotation; sometimes distributes roles according to the interest of work" with an arithmetic mean of (2.05). The general arithmetic mean of this area was (2.13) and the standard deviation was (0.70) indicating that the extent of school managers' practicing of leadership styles according to the Managerial Grid Model in Al-Batinah North Governorate, Sultanate of Oman from the point of view of senior teachers is low according to the Pendulum Management Style. This result may be due to that school managers act as mediators between teachers' needs/requirements and work needs/requirements, and try to compromise and resolve the contradictions between the goals of the two parties achieving the goals of the educational learning process. Furthermore, they deal with teachers in a manner not bothering them and sometimes use power to control their actions.

\section{Fifth: Team management}

Table (9) the Arithmetic Means and Standard Deviations of Items of the Fifth Style (Team Management) in a descending order according to the Arithmetic Means

\begin{tabular}{|c|c|c|c|c|c|}
\hline Rank & Number & Items & $\begin{array}{l}\text { Arithmetic } \\
\text { Mean }\end{array}$ & $\begin{array}{l}\text { Standard } \\
\text { Deviation }\end{array}$ & $\begin{array}{l}\text { Degree of } \\
\text { Practice }\end{array}$ \\
\hline 1 & 25 & $\begin{array}{l}\text { Believes that teamwork is a } \\
\text { cornerstone for achieving goals }\end{array}$ & 4.48 & 0.76 & high \\
\hline 2 & 30 & $\begin{array}{l}\text { Maintains objectivity when } \\
\text { evaluating teachers }\end{array}$ & 4.29 & 0.85 & high \\
\hline 3 & 28 & $\begin{array}{l}\text { Search for decisions that balance } \\
\text { work requirements and employee } \\
\text { circumstances }\end{array}$ & 4.28 & 0.82 & high \\
\hline 4 & 27 & $\begin{array}{l}\text { Allows teachers to express their } \\
\text { opinions in work and to present new } \\
\text { ideas }\end{array}$ & 4.25 & 0.93 & high \\
\hline 5 & 29 & $\begin{array}{l}\text { Fair in dealings with teachers } \\
\text { Leads work team meetings effectively }\end{array}$ & 4.23 & 0.85 & $\begin{array}{l}\text { high } \\
\text { high }\end{array}$ \\
\hline 6 & 26 & $\begin{array}{l}\text { and democratically according to a } \\
\text { specific timetable }\end{array}$ & 4.17 & 0.92 & \\
\hline & & General Level & 4.29 & 0.72 & high \\
\hline
\end{tabular}

Table (9) shows the general arithmetic means and the general standard deviation of the items of the fifth style (Team Management) where the general arithmetic means was (4.29) and the general standard deviation was (0.72) with high degree. In the first place came Item (25) "Believes that teamwork is a cornerstone for achieving goals" with the highest arithmetic mean of (4.48). In the second place came Item (30) "Maintains objectivity when evaluating teachers" with an arithmetic mean of (4.29). In the third place came Item (28) "Search for decisions that balance work requirements and employee circumstances" with an arithmetic mean of (4.28). In the last place came Item (26) "Leads work team meetings effectively and democratically according to a specific timetable" with an arithmetic mean of (4.17). The general arithmetic mean of this area was (4.29) and the standard deviation was (0.72) indicating that the extent of school managers' practicing of leadership styles according to the Managerial Grid Model in AlBatinah North Governorate, Sultanate of Oman from the point of view of senior teachers is high according to the Team Management Style. This result may be due to that school managers allow teachers express their opinions at work and put forward ideas supporting various educational programs, believing in the importance of the ideas presented by the subordinates 
and the balance among work requirements. This also can be attributed to the awareness of school managers of the importance of teamwork and the positive results that may be achieved by the team in general. In addition, school managers realize the importance of time management and work to reduce waste in order to improve the educational learning process. This result was consistent with the result of the studies of (Al-Jasasi, 2016; Al Ash, 2010).

Second: Results related to the second questions, which read:

"Are there statistically significant differences at the level of $(\alpha \leq 0.05)$ in the extent of school managers' practicing of leadership styles according to the Managerial Grid Model in AlBatinah North Governorate, Sultanate of Oman due to the gender, academic qualification and experience years?"

To answer this question, data was analyzed to calculate the arithmetic means and standard deviations for scores of the study sample regarding the extent of school managers' practicing of leadership styles according to the Managerial Grid Model in Al-Batinah North Governorate, Sultanate of Oman. These means were compared using T test and ANOVA in order to verify the significance of differences attributed to variables of gender, academic qualification, and years of experience, as follows:

\section{"Gender" Variable:}

The arithmetic means and standard deviations were calculated and $\mathrm{T}$ test was conducted to the independent sample to know the effect of gender variable (male \& female) as shown in the following Table.

Table (10) T-Test for Gender Variable Effect on the Extent of School Managers' Practicing of Leadership Styles according to the Managerial Grid Model in Al-Batinah North Governorate, Sultanate of Oman

\begin{tabular}{lcccccc}
\multicolumn{1}{c}{ Styles } & Gender & $\begin{array}{c}\text { Number } \\
\text { N=350 }\end{array}$ & $\begin{array}{c}\text { Arithmetic } \\
\text { Mean }\end{array}$ & $\begin{array}{c}\text { Standard } \\
\text { Deviation }\end{array}$ & T value & $\begin{array}{c}\text { Statistical } \\
\text { Significance }\end{array}$ \\
\hline Impoverished & Male & 175 & 2.83 & 0.84 & $2.442-$ & 0.815 \\
Management & Female & 175 & 3.05 & 0.85 & & \\
Scientific & Male & 175 & 2.40 & 0.54 & 0.290 & 0.026 \\
Management & Female & 175 & 2.39 & 0.62 & & \\
Social Club & Male & 175 & 3.85 & 0.75 & $2.373-$ & 0.017 \\
Management & Female & 175 & 4.02 & 0.59 & & \\
Pendulum & Male & 175 & 2.21 & 0.74 & 2.017 & 0.049 \\
Management & Female & 175 & 2.06 & 0.66 & & \\
Team Management & Male & 175 & 4.14 & 0.78 & $3.706-$ & 0.015 \\
& Female & 175 & 4.43 & 0.64 & &
\end{tabular}

From Table (10), there are no statistically significant differences at the level of $(\alpha \leq 0.05)$ in scores of study sample regarding the extent of school managers' practicing of leadership styles according to the Managerial Grid Model in Al-Batinah North Governorate, Sultanate of Oman due to gender in all study areas. This result may be due to that school managers adhere to the educational laws and regulations applicable in all schools. It may also be attributed to the fact that the teachers with their different gender work according to work regulations, laws and instructions that are predetermined, making teachers' opinions and views closer to each other regardless of their experiences.

\section{“Academic Qualification" Variable:}

The arithmetic means and standard deviations were calculated for scores of the study sample regarding the extent of school managers' practicing of leadership styles according to the 
Managerial Grid Model in Al-Batinah North Governorate, Sultanate of Oman according to variable of academic qualification (diploma, Bachelor of Arts, Master and higher) as shown in the following Table.

Table (11) the arithmetic means and standard deviations for the effect of the academic qualification variable on the extent of school managers' practicing of leadership styles according to the Managerial Grid Model in Al-Batinah North Governorate

\begin{tabular}{lllccccc}
$\begin{array}{l}\text { Academic } \\
\text { Qualification }\end{array}$ & $\begin{array}{l}\text { Number } \\
\mathrm{N}=350\end{array}$ & $\begin{array}{c}\text { Impoverished } \\
\text { Management }\end{array}$ & $\begin{array}{c}\text { Scientific } \\
\text { Management }\end{array}$ & $\begin{array}{c}\text { Social Club } \\
\text { Management }\end{array}$ & $\begin{array}{c}\text { Pendulum } \\
\text { Management }\end{array}$ & $\begin{array}{c}\text { Team } \\
\text { Management }\end{array}$ \\
\hline Diploma & \multirow{2}{*}{36} & arithmetic mean & 2.67 & 2.36 & 3.91 & 2.30 & 4.13 \\
Bachelor of & & standard deviation & 0.91 & 0.58 & 0.73 & 0.81 & 0.79 \\
Arts & \multirow{2}{*}{286} & arithmetic mean & 2.97 & 2.39 & 3.95 & 2.10 & 4.32 \\
Master and & & standard deviation & 0.83 & 0.59 & 0.65 & 0.67 & 0.69 \\
higher & \multirow{2}{*}{ arithmetic mean } & 2.97 & 2.54 & 3.80 & 2.24 & 4.16 \\
Total & & standard deviation & 0.97 & 0.46 & 0.88 & 0.82 & 0.90 \\
& & arithmetic mean & 2.94 & 2.39 & 3.93 & 2.13 & 4.29 \\
& \multirow{2}{*}{350} & standard deviation & 0.85 & 0.58 & 0.68 & 0.70 & 0.72
\end{tabular}

Table (11) shows a close variance in the arithmetical means and standard deviations of the study sample scores regarding the extent of school managers' practicing of leadership styles according to the Managerial Grid Model in Al-Batinah North Governorate, Sultanate of Oman according to variable of academic qualification. In order to ascertain the significance of the statistical differences between the arithmetic means, the ANOVA was used, as shown in the following Table.

Table (12) ANOVA for the effect of the academic qualification variable on the extent of school managers' practicing of leadership styles according to the Managerial Grid Model in Al-Batinah North Governorate

\begin{tabular}{llccccc} 
Styles & Source & $\begin{array}{c}\text { Total } \\
\text { Squares }\end{array}$ & $\begin{array}{c}\text { Freedom } \\
\text { Degrees }\end{array}$ & $\begin{array}{c}\text { Mean } \\
\text { Square }\end{array}$ & F Value & $\begin{array}{c}\text { Statistical } \\
\text { Significance }\end{array}$ \\
\hline Impoverished & Between groups & 2.952 & 2 & 1.476 & 2.051 & 0.130 \\
Management & Within groups & 249.769 & 347 & 0.72 & & \\
& Total & 252.722 & 349 & & & \\
Scientific & Between groups & 0.632 & 2 & 0.316 & 0.93 & 0.396 \\
Management & Within groups & 117.964 & 347 & 0.34 & & \\
& Total & 118.596 & 349 & & & \\
Social Club & Between groups & 0.596 & 2 & 0.298 & 0.643 & 0.526 \\
Management & Within groups & 160.924 & 347 & 0.464 & & \\
& Total & 161.521 & 349 & & & \\
Pendulum & Between groups & 1.534 & 2 & 0.767 & 1.566 & 0.210 \\
Management & Within groups & 169.966 & 347 & 0.49 & & \\
& Total & 171.5 & 349 & & & \\
Team & Between groups & 1.595 & 2 & 0.797 & 1.534 & 0.217 \\
Management & Within groups & 180.346 & 347 & 0.52 & & \\
& Total & 181.94 & 349 & & &
\end{tabular}

From Table (12), there are no statistically significant differences at the level of $(\alpha \leq 0.05)$ in scores of study sample regarding the extent of school managers' practicing of leadership styles according to the Managerial Grid Model in Al-Batinah North Governorate, Sultanate of Oman due to academic qualification in all study areas. This result may be due to that tasks assigned to school managers are very similar regardless of their qualifications, and leadership styles are not based on a certain qualification rather than another. This result differed from the result of the study of (Wijdan, 2014). 


\section{"Years of Experience" Variable:}

The arithmetic means and standard deviations were calculated and T test was conducted to the independent sample to know the effect of years of experience variable (15 years and less \& 16 years and over) as shown in the following Table.

Table (13) T-Test for Years of Experience Variable Effect on the Extent of School Managers' Practicing of Leadership Styles according to the Managerial Grid Model in Al-Batinah North

\begin{tabular}{llccccc} 
& \multicolumn{2}{c}{ Governorate, Sultanate of Oman } \\
Styles & \multicolumn{1}{c}{$\begin{array}{c}\text { Years of } \\
\text { Experience }\end{array}$} & $\begin{array}{c}\text { Number } \\
\text { N=350 }\end{array}$ & $\begin{array}{c}\text { Arithmetic } \\
\text { Mean }\end{array}$ & $\begin{array}{c}\text { Standard } \\
\text { Deviation }\end{array}$ & T value & $\begin{array}{c}\text { Statistical } \\
\text { Significance }\end{array}$ \\
\hline Impoverished & 15 years and less & 210 & 2.97 & 0.80 & 0.808 & 0.080 \\
Management & 16 years and over & 140 & 2.89 & 0.93 & & \\
Scientific & 15 years and less & 210 & 2.40 & 0.58 & 0.330 & 0.987 \\
Management & 16 years and over & 140 & 2.38 & 0.58 & & \\
Social Club & 15 years and less & 210 & 3.92 & 0.71 & $0.363-$ & 0.435 \\
Management & 16 years and over & 140 & 3.95 & 0.64 & & \\
Pendulum & 15 years and less & 210 & 2.13 & 0.72 & $0.207-$ & 0.332 \\
Management & 16 years and over & 140 & 2.14 & 0.67 & & \\
Team & 15 years and less & 210 & 4.27 & 0.77 & $0.453-$ & 0.047 \\
Management & 16 years and over & 140 & 4.31 & 0.65 & &
\end{tabular}

From Table (13), there are no statistically significant differences at the level of $(\alpha \leq 0.05)$ in scores of study sample regarding the extent of school managers' practicing of leadership styles according to the Managerial Grid Model in Al-Batinah North Governorate, Sultanate of Oman due to years of experience variable (15 years and less \& 16 years and over) in all Scale dimensions except the fifth style (Team Management) in which the statistically significant differences were in favor of the sample with 16 years and over. This result may be attributed to that people with 16 years and over are more manageable for work teams due to their outstanding accumulated technical and managerial experiences. This result differed from the result of the study of (Recthard, 2005).

Third: Results related to the third question, which read:

"What is the level of job satisfaction among senior teachers in schools of in Al-Batinah North Governorate, Sultanate of Oman?"

To answer this question, the arithmetic means and standard deviations were calculated for scores of the study sample regarding the level of job satisfaction among sample of senior teachers in Al-Batinah North Governorate, Sultanate of Oman according to the dimensions of Job Satisfaction Scale. To clarify the results of answering this question, the researcher adopted the following arbitration:

\begin{tabular}{lcc}
\hline & Range & $\begin{array}{c}\text { Degree of Job } \\
\text { Satisfaction }\end{array}$ \\
\hline From 1 to 2.33 & low \\
From 2.34 to 3.67 & average \\
From 3.68 to 5 & high \\
\hline
\end{tabular}

The following Table shows this. 
Table (14) the Arithmetic Means and Standard Deviations were calculated for Scores of the Study Sample on the Dimensions of Job Satisfaction Scale in a Descending Order according to the Arithmetic Means

\begin{tabular}{|c|c|c|c|c|c|}
\hline Rank & Number & Dimensions & $\begin{array}{l}\text { Arithmetic } \\
\text { Mean }\end{array}$ & $\begin{array}{l}\text { Standard } \\
\text { Deviation }\end{array}$ & $\begin{array}{l}\text { Level of } \\
\text { Satisfaction }\end{array}$ \\
\hline 1 & 4 & $\begin{array}{l}\text { Fourth Dimension: Satisfaction with } \\
\text { the school managers' policies }\end{array}$ & 4.28 & 0.72 & high \\
\hline 2 & 3 & $\begin{array}{l}\text { Third Dimension: Satisfaction with } \\
\text { teacher's evaluation of his/her } \\
\text { profession }\end{array}$ & 4.16 & 0.67 & high \\
\hline 3 & 2 & $\begin{array}{l}\text { Second Dimension: Satisfaction with } \\
\text { work environment }\end{array}$ & 3.79 & 0.78 & high \\
\hline \multirow[t]{2}{*}{4} & 1 & $\begin{array}{l}\text { First Dimension: Satisfaction with } \\
\text { salary }\end{array}$ & 2.88 & 0.87 & average \\
\hline & & Job Satisfaction Scale in total & 3.78 & 0.58 & high \\
\hline
\end{tabular}

Table (14) shows the arithmetic means and standard deviations for scores of the study sample regarding the level of job satisfaction among sample of senior teachers in Al-Batinah North Governorate, Sultanate of Oman according to the dimensions of Job Satisfaction Scale. In the first place came the fourth dimensions (Satisfaction with the school managers' policies) with the highest arithmetic mean of (4.28) and a standard deviation of (0.72). In the second place came the third dimension (Satisfaction with teacher's evaluation of his/her profession) with an arithmetic mean of (4.16) and a standard deviation of (0.67). In the third place came the second dimension (Satisfaction with work environment) with an arithmetic mean of (3.79) and a standard deviation of (0.78). In the last place came the first dimension (Satisfaction with salary) with an arithmetic mean of (2.88) and a standard deviation of (0.87). The general arithmetic mean of the Scale as a whole was (3.78) and a general standard deviation of (0.58) with high level of job satisfaction among the sample member.

This result is attributed to the fact that the Ministry of Education has contributed greatly to making the level of job satisfaction high. The Ministry has provided an attractive comfortable environment for the teacher in the educational field, thus a private hall and offices are provided for teachers making all amenities available, such as water, ventilation, air conditioning, lighting and food as well as Internet service in the halls/rooms of teachers. Furthermore, the school building is equipped with various audiovisual techniques designated for the teacher, so that he/she can innovate and presents his/her experiences with good quality. This is despite the suspension of the teachers' promotions and the lack of incentives for quite some time due to the economic conditions encountered by the State and the world as a whole. The present study result is consistent with the study of (Haddad and Mohafazah, 2010) that all respondents received high level of job satisfaction. The study is also consistent with the study of Al-Rawqi (2011) that there was a high level of job satisfaction in terms of teachers' views. 


\section{First: the first dimension (satisfaction with salary):}

Table (15) the Arithmetic Means and Standard Deviations of the Items of the First Dimension (Satisfaction with Salary) in a Descending Order according to the Arithmetic Means

\begin{tabular}{cclccc} 
Rank & Number & \multicolumn{1}{c}{ Items } & $\begin{array}{c}\text { Arithmetic } \\
\text { Mean }\end{array}$ & $\begin{array}{c}\text { Standard } \\
\text { Deviation }\end{array}$ & $\begin{array}{c}\text { Level of } \\
\text { Satisfaction }\end{array}$ \\
\hline 1 & 4 & $\begin{array}{l}\text { I am bothered for the lack of promotional } \\
\text { rewards in recognition of my efforts. }\end{array}$ & 3.70 & 1.39 & low \\
2 & 6 & $\begin{array}{l}\text { Ignoring my financial promotion affects my } \\
\text { career. }\end{array}$ & 3.61 & 1.45 & average \\
3 & 1 & $\begin{array}{l}\text { My salary is appropriate to the nature of my } \\
\text { work. }\end{array}$ & 2.87 & 1.36 & average \\
4 & 5 & $\begin{array}{l}\text { Salary is appropriate to the degree I hold. } \\
\text { Salary is appropriate to my years of experience. }\end{array}$ & 2.77 & 1.35 & average \\
& 3 & $\begin{array}{l}\text { My promotion decisions are made in a fair } \\
\text { manner. }\end{array}$ & 2.00 & 1.32 & average \\
6 & 2 & 2.88 & 0.87 & low \\
\hline
\end{tabular}

Table (15) shows the general arithmetic mean and the general standard deviation for the items of the first dimension (Satisfaction with salary) where the general arithmetic mean of the dimension was (2.88) and a general standard deviation of (0.87) with average degree. In the first place came Item (4) "I am bothered for the lack of promotional rewards in recognition of my efforts." with the highest arithmetic mean of (3.70). In the second place came Item (6) "Ignoring my financial promotion affects my career" with an arithmetic mean of (3.61). In the third place came Item (1) "My salary is appropriate to the nature of my work" with an arithmetic mean of (2.87). In the last place came the Item (2) "My promotion decisions are made in a fair manner" with an arithmetic mean of (2.00). This result is attributed to the subjectivity in promotion of teachers, in addition to the limited role of the school manager in granting bonuses/rewards to teachers as this is one of the powers of the Ministry of Education.

\section{Second: the second dimension (satisfaction with work environment):}

Table (16) the Arithmetic Means and Standard Deviations of the Items of the Second Dimension (Satisfaction with Work Environment) in a Descending Order according to the Arithmetic Means

\begin{tabular}{|c|c|c|c|c|c|}
\hline Rank & Number & Items & $\begin{array}{l}\text { Arithmetic } \\
\text { Mean }\end{array}$ & $\begin{array}{l}\text { Standard } \\
\text { Deviation }\end{array}$ & $\begin{array}{c}\text { Level of } \\
\text { Satisfaction }\end{array}$ \\
\hline 1 & 7 & $\begin{array}{l}\text { The school management considers } \\
\text { material factors such as ventilation, } \\
\text { lighting, etc. }\end{array}$ & 4.14 & 0.91 & high \\
\hline 2 & 8 & My place of work is always clean. & 4.00 & 0.96 & high \\
\hline 2 & 11 & I feel secure and job stability in my job. & 4.00 & 0.97 & high \\
\hline 3 & 12 & $\begin{array}{l}\text { Working hours are suitable for my } \\
\text { personal circumstances. }\end{array}$ & 3.55 & 1.23 & average \\
\hline 4 & 9 & $\begin{array}{l}\text { School management takes into } \\
\text { consideration that the students' number } \\
\text { is appropriate to the classroom. }\end{array}$ & 3.53 & 1.19 & average \\
\hline \multirow[t]{2}{*}{4} & 10 & $\begin{array}{l}\text { The school provides appropriate breaks } \\
\text { during work. }\end{array}$ & 3.53 & 1.13 & average \\
\hline & & General Level & 3.79 & 0.78 & high \\
\hline
\end{tabular}


Table (16) shows the general arithmetic mean and the general standard deviation for the items of the second dimension (Satisfaction with work environment) where the general arithmetic mean of the dimension was (3.79) and a general standard deviation of (0.78) with average degree. In the first place came Item (7) "The school management considers material factors such as ventilation, lighting, etc." with the highest arithmetic mean of (4.14). In the second place came Items (8 \& 11) "My place of work is always clean" "I feel secure and job stability in my job" respectively with the same arithmetic mean of (4.00). In the third place came Item (12) "Working hours are suitable for my personal circumstances" with an arithmetic mean of (3.55). In the last place came the Items (9\& 10) "School management takes into consideration that the students' number is appropriate to the classroom" "The school provides appropriate breaks during work" respectively with the same arithmetic mean of (3.53). This result is attributed to the great efforts of the Ministry of Education, such as provision of most of teachers' needs, such as the building, facilities, furniture, security and safety. The Ministry is also keen to recruit teachers in the nearest schools to their homes. It may also be attributed to the great role played by the Ministry of Education in its various sectors to make its employees more comfortable and to provide functional security in addition to the way of setting school schedules in such a way providing sufficient time for teachers. The proof is that most teachers have enough consecutive classes so that the teacher can have rest to be able to follow up his/her non-classroom work of any kind inside the work environment. This study is consistent with study of Rasheed (2016) on job satisfaction with the work environment and its conditions. The level of job satisfaction in the two studies was high in general.

Third: third dimension: Satisfaction with teacher's evaluation of his/her profession:

Table (17) the Arithmetic Means and Standard Deviations of the Items of the Third Dimension (Satisfaction with teacher's evaluation of his/her profession) in a Descending Order according to the Arithmetic Means

\begin{tabular}{|c|c|c|c|c|c|}
\hline Rank & Number & Items & $\begin{array}{l}\text { Arithmetic } \\
\text { Mean }\end{array}$ & $\begin{array}{l}\text { Standard } \\
\text { Deviation }\end{array}$ & $\begin{array}{l}\text { Level of } \\
\text { Satisfaction }\end{array}$ \\
\hline 1 & 15 & $\begin{array}{l}\text { Follows up my technical and administrative } \\
\text { records from time to time. }\end{array}$ & 4.30 & 0.73 & high \\
\hline 2 & 14 & $\begin{array}{l}\text { Encourages teachers to use different teaching } \\
\text { methods. }\end{array}$ & 4.29 & 0.79 & high \\
\hline 3 & 16 & $\begin{array}{l}\text { Gives teachers the adequate opportunity to self- } \\
\text { assess. }\end{array}$ & 4.16 & 0.80 & high \\
\hline 4 & 17 & Appreciates my effort in teaching. & 4.14 & 0.88 & high \\
\hline 5 & 13 & $\begin{array}{l}\text { Conducts a standardized assessment for all } \\
\text { schoolteachers. }\end{array}$ & 4.07 & 0.85 & high \\
\hline \multirow[t]{2}{*}{6} & 18 & $\begin{array}{l}\text { Meets the professional needs and desires of } \\
\text { teachers. }\end{array}$ & 3.98 & 0.91 & high \\
\hline & & General level & 4.16 & 0.67 & high \\
\hline
\end{tabular}

Table (17) shows the general arithmetic mean and the general standard deviation for the items of the third dimension (Satisfaction with teacher's evaluation of his/her profession) where the general arithmetic mean of the dimension was (4.16) and a general standard deviation of (0.67) with high degree. In the first place came Item (15) "Follows up my technical and administrative records from time to time" with the highest arithmetic mean of (4.30). In the second place came Item (14) "Encourages teachers to use different teaching methods" with an arithmetic mean of (4.29). In the third place came Item (16) "Gives teachers the adequate opportunity to self-assess" with an arithmetic mean of (4.16). In the last place came the Item (18) "Meets the professional needs and desires of teachers" with an arithmetic mean of (3.98). This result may be attributed to that teachers are satisfied with their school managements through technical and administrative follow-ups in evaluation of teachers. School managers are 
keen to protect themselves and their teachers from committing any external technical and administrative mistakes. Teacher also clrealy desire to make professional development, whether individually or through professional development programs in education field. This study differs with the study of Dahlan (2013) in terms of satisfaction with teacher's evaluation of his/her profession and his/her belonging to work. The result of the present study shows statistically significant differences at the level of $(\alpha \leq 0.05)$ in the scores of study sample regarding job satisfaction. On the other hand, Dahlan study indicated that there are no statistically significant differences in the scores of study sample for areas similar to the areas of this study, such as nature of work, security, and belonging to work.

\section{Fourth: fourth dimension: Satisfaction with the school manager's policies:}

Table (18) the Arithmetic Means and Standard Deviations of the Items of the Third Dimension (Satisfaction with the school manager's policies) in a Descending Order according to the Arithmetic Means

\begin{tabular}{|c|c|c|c|c|c|}
\hline Rank & Number & Items & $\begin{array}{l}\text { Arithmetic } \\
\text { Mean }\end{array}$ & $\begin{array}{l}\text { Standard } \\
\text { Deviation }\end{array}$ & $\begin{array}{l}\text { Level of } \\
\text { Satisfaction }\end{array}$ \\
\hline 1 & 24 & $\begin{array}{l}\text { I have good relationship with my } \\
\text { manager. }\end{array}$ & 4.57 & 0.74 & high \\
\hline 2 & 22 & $\begin{array}{l}\text { My managers treat teacher with } \\
\text { respect and trust. }\end{array}$ & 4.41 & 0.78 & high \\
\hline 3 & 20 & $\begin{array}{l}\text { My manager gives clear instructions at } \\
\text { work. }\end{array}$ & 4.25 & 0.82 & high \\
\hline 4 & 19 & $\begin{array}{l}\text { My manager helps me in work } \\
\text { difficulties. }\end{array}$ & 4.20 & 0.86 & high \\
\hline 5 & 23 & $\begin{array}{l}\text { My manager engages teachers in } \\
\text { constant career growth for them. }\end{array}$ & 4.16 & 0.96 & high \\
\hline \multirow[t]{2}{*}{6} & 21 & $\begin{array}{l}\text { My manager listen well to my } \\
\text { suggestions. }\end{array}$ & 4.11 & 0.96 & high \\
\hline & & General Level & 4.28 & 0.72 & high \\
\hline
\end{tabular}

Table (18) shows the general arithmetic mean and the general standard deviation for the items of the fourth dimension (Satisfaction with the school manager's policies) where the general arithmetic mean of the dimension was (4.28) and a general standard deviation of (0.72) with high degree. In the first place came Item (24) "I have good relationship with my manager" with the highest arithmetic mean of (4.57). In the second place came Item (22) "My managers treat teacher with respect and trust" with an arithmetic mean of (4.41). In the third place came Item (20) "My manager gives clear instructions at work" with an arithmetic mean of (4.25). In the last place came the Item (21) "My manager listen well to my suggestions" with an arithmetic mean of (4.11). This result may be attributed to that school managers and senior teachers are greatly close to each other because they form various councils and school committees, making their ideas much closer in each small and large detail related to work and employees at the school. In addition, school managers treat teachers respectfully, so there are good relationships between school managements and teachers. The application of principle of disagreement doesn't damage amicability because school managers apply open door policy to gain creative ideas and suggestions from teachers enabling school managers from benefiting from work and employees altogether. The present study is consistent with the study of Iqbal \& Akhtar in terms of great satisfaction between male and female teachers in matters related to work and supervision of the job by school managers. 
Fifth: Results related to the fifth question, which read:

"Is there a relationship between the extent of school managers' practicing of leadership styles and job satisfaction of sample of senior teachers in Al-Batinah North Governorate, Sultanate of Oman?"

To answer this question, Pearson correlation coefficient was extracted to know the relationship between the extent of school managers' practicing of leadership styles and job satisfaction of sample of senior teachers in Al-Batinah North Governorate, Sultanate of Oman.

To illustrate the results of the question, the researcher adopted the following table to explain the correlation coefficient:

\begin{tabular}{lll}
\hline correlation coefficient & degree & direction \\
\hline$-1-$ less than 0.000 & low & negative $(-)$ \\
$0.001-$ less than 0.30 & very low & positive $(+)$ \\
$0.30 —$ less than 0.50 & low & positive $(+)$ \\
$0.50-$ less than 0.70 & average & positive $(+)$ \\
$0.70-$ less than 0.90 & high & positive $(+)$ \\
$0.90-1$ & very high & positive $(+)$ \\
\hline
\end{tabular}

The following Table show this.

Table (19): Pearson correlation coefficient for the relationship between the extent of school managers' practicing of leadership styles and job satisfaction of sample of senior teachers in AlBatinah North Governorate

\begin{tabular}{llccccc}
\hline $\begin{array}{l}\text { Leadership Styles } \\
\text { Practicing Scale }\end{array}$ & Correlation & salary & $\begin{array}{c}\text { Job Satisfaction Scale } \\
\text { work } \\
\text { environment }\end{array}$ & $\begin{array}{c}\text { teacher's } \\
\text { evaluation of } \\
\text { his/her work }\end{array}$ & $\begin{array}{c}\text { chool } \\
\text { manager's } \\
\text { policies }\end{array}$ & $\begin{array}{c}\text { Scale as a } \\
\text { whole }\end{array}$ \\
Impoverished & Coefficient (r) & $.150-* *$ & $.133-*$ & $.047-$ & $.085-$ & $.141-^{* *}$ \\
Management & Significance & 0.005 & 0.013 & 0.376 & 0.113 & 0.008 \\
Scientific & Coefficient (r) & $.054-$ & 0.001 & 0.04 & $.028-$ & $.017-$ \\
Management & Significance & 0.315 & 0.99 & 0.459 & 0.607 & 0.749 \\
Social Club & Coefficient (r) & $.200^{* *}$ & $.342^{* *}$ & $.378^{* *}$ & $.473^{* *}$ & $.447^{* *}$ \\
Management & Significance & 0.000 & 0.000 & 0.000 & 0.000 & 0.000 \\
Pendulum & Coefficient (r) & $.254-* *$ & $.471^{* *}$ & $.513-^{* *}$ & $.507-* *$ & $.560-* *$ \\
Management & Significance & 0.000 & 0.000 & 0.000 & 0.000 & 0.000 \\
Team & Coefficient (r) & 0.102 & $.416^{* *}$ & $.619^{* *}$ & $.671^{* *}$ & $.566^{* *}$ \\
Management & Significance & 0.056 & 0.000 & 0.000 & 0.000 & 0.000 \\
Scale as a whole & Coefficient (r) & $.091-$ & 0.065 & $.235^{* *}$ & $.260^{* *}$ & $.137^{*}$ \\
& Significance & 0.089 & 0.225 & 0.000 & 0.000 & 0.011 \\
\hline
\end{tabular}

** Significance level of $(\alpha \leq 0.01)$.

* Significance level of $(\alpha \leq 0.05)$.

Table (19) shows that there is a statistically significant correlation at the level of $(\alpha \leq 0.01)$ between the extent of school managers' practicing of leadership styles and job satisfaction of sample of senior teachers in Al-Batinah North Governorate, Sultanate of Oman. It is worth mentioning that the correlation coefficient between them is positive and very low with direct relationship. This means the higher the practice of managers for leadership styles, the higher 
the degree of job satisfaction among senior teachers. The statistical significance between the two scales is $(0.011)$ in general and Pearson correlation coefficient is $\left(r=.137^{*}\right)$.

The results of the Pearson correlation coefficients ( $\mathrm{r}$ ) between the dimensions of the two Scales indicate the following:

- There is a negative and low correlation between the first style (Impoverished Management), the two dimensions of job satisfaction (satisfaction with salary, satisfaction with work environment) and job satisfaction as a whole. There is no statistically significant correlation between the first style (Impoverished Management), and the two dimensions of job satisfaction (satisfaction with the teacher's evaluation of his/her profession, satisfaction with the school managers' policies).

- There is no statistically significant correlation between the second style (Scientific Management), all dimensions of job satisfaction and the total score of the Scale.

- There is a positive and low statistically significant correlation between the third style (Social Club Management), all dimensions of job satisfaction and the total score of the Scale.

- There is a negative and low statistically significant correlation between the fourth style (Pendulum Management), all dimensions of job satisfaction and the total score of the Scale.

- There is a positive and average statistically significant correlation between the fifth style (Team Management), all dimensions of job satisfaction and the total score of the Scale except the first dimension (satisfaction with salary) where there is no correlation between them. This low correlation may be due to the different nature between leadership styles; some are positive, such as Team Management and Social Club Management, while the other are negative having bad effect on the school management, such as Impoverishment Management, Scientific Management and Pendulum Management. The proof is the negative correlation caused by the Impoverishment Management Style and that negative correlation caused by the Impoverishment Management in all dimensions of job satisfaction. On the other hand, Team Management and Social Club Management have positive effect on job satisfaction among senior teachers. This study is consistent with the study of Al-Rawqi (2011) in some aspects in terms of a positive direct correlation with average degree between job satisfaction and the democratic style. This applies to Team Management and Social Club Management styles, which positively affects job satisfaction of senior teachers of this study.

\section{RECOMMENDATIONS}

Based on the results of this study, the two researchers recommend the following:

- School managers should avoid raising disputes among teachers while dealing with them.

- School managers should not be hesitated when making administrative decisions.

- School managers should involve teachers in decision-making related to the school.

- School managers should pre-determine dates of meetings with teachers.

- School managers should not make decisions solely or consider these decisions irrevocable.

\section{References:}

\section{First: Arabic References:}

Al-Jasasi, Badriya bint Mubarak (2016). "Leadership styles of post-primary schools managers in the Sultanate of Oman according to the Path-Goal Theory from the point of view of school managers and their relation to teachers' job satisfaction." Published Master Thesis, University of Nizwa. 
Al Har, Abdul Aziz Mohammed (2017). "Leadership in Future Schools”, Saudi Arabia: Arab Education Office.

Al-Rawqi, Ayed Abdullah (2011). "Leadership styles of school managers and their relation to job satisfaction among high school teachers in Makkah ". Unpublished Thesis, Umm Al Qura University, Makkah, Saudi Arabia.

Rifa'i, Zahra Sayed (2013). "The relationship of the transformational and transactional leadership styles for the high school managers in the State of Kuwait with teachers' empowerment from their point of view." Published Master Thesis, Middle East University. Jordan.

Al Azraq, Abdulrahman (2000). Educational psychology of teachers. Beirut: Dar Al Fikr Al Lubnani.

Ajami, Mohammed Hussein, Hassan, Hassan Mohammed Ibrahim (2007). Educational administration. Edition 1. Amman: Dar Al Massira for Publishing, Printing \& Distribution.

Al Ash, Nadia Tahseen Hassan (2014). "Leadership styles for public high school managers in Jordan according to the Managerial Grid Model and their relation to the level of work stress among teachers." Published Master Thesis, Amman Arab University, Jordan.

Al Anzi, Maha Issa Hamad. (2014). "The extent of educational supervisors' practicing of leadership styles according to the Managerial Grid Model from the point of view of teachers in Kuwait." Published Master Thesis, $\mathrm{Al}$ al-Bayt University, Jordan.

Bataineh, Wijdan Mohammed (2014). “The extent of high school managers' practicing of leadership styles and its relation to teachers' job satisfaction from their point of view." Published Master Thesis, Jerash University, Jordan.

Haddad, Rabie, Sameh, Mohafazah (2010). "Leadership styles of the primary school managers in Ajloun Governorate and their relation to employees' job satisfaction from the point of view of the employees themselves in the Hashemite Kingdom of Jordan." Journal of Educational Sciences, 37 (2), 402-403.

Harim, Hussein (1997). “Organizational behavior, behavior of individuals in organizations. Amman: Zahran Publishing House.

Hammadi, Ahmed Abbas (2016). "Administrative empowerment and its relation to job satisfaction: a survey study of the opinions of a sample of public directors in the Ministry of Planning and Development Cooperation, Central Organization for Standardization and Quality Control. AL-Anbar University journal of Economic and Administration Sciences, 8 (16), 116117.

Dahlan, Samira Yahya (2013), "Leadership styles of high school managers in Gaza Governorates and their relation to teachers' job satisfaction." Published Master Thesis, Al-Azhar University in Gaza, Palestine.

Rawashdeh, Asmaa Mashhour (2009). "Leadership styles public high school managers in Zarqa Governorate according to the Managerial Grid Model from the point of view of teachers, and their relation to job satisfaction." Published Master Thesis published, Hashemite University, Jordan.

Obaidat, Suhail Ahmed (2003). "Leadership styles according to the Managerial Grid Model and its relation to the effectiveness of time management among public high school managers in Jordan from their point of view". PhD thesis, Amman Arab University, Jordan.

Issan, Salehah Abdullah, Al-Shaidi and Fa'iza bint Ahmed (2018). "The degree of applying comprehensive quality criteria in the post-primary education schools from the point of view of the educational supervisors and the senior teachers in the Sultanate of Oman." Journal of Educational and Psychological Studies, Sultan Qaboos University, 12 (2), 262-281.

\section{Second: Foreign References:}

Agnihotri, A. (2013). Job satisfaction among school teachers. Indian Streams Research Journal, 3(2), pp 1- 7.

Krause, G.A. \& Meier, K.j. (2003).politics Policy, and Organizations: Frontiers in the scientific study of Bureaucracy, University of Michigan press, p6.

Sweet, Kati; Bruce, Jackie. (2016). Teaching GLEE - dership. Journal of Leadership Education, 15, (1), pp 171 177.

Iqbal, A. \& Akhtar, S. (2013). Job satisfaction of secondary school teachers. Abasyn Journal of Social Sciences, 5(1), pp $49-65$.

Richard, J. (2005). Principal behaviors that encourage teachers: Perception of teachers at three career stages. Paper presented at the Annual Meeting of the American Educational Research Association (Eric document reproduction Serrice No ED490357).

Taleb, H. (2013). "Gender and leadership style in Educational Institutions", International Journal for educational management. 2 (1). 